\title{
CELLULASE PRODUCTION BY Bacillus subtilis M1USING PRETREATED GROUNDNUT SHELL BASED LIQUID STATE FERMENTATION
}

\author{
ASHISH VYAS ${ }^{1 *}$, CHAYANIKA PUTATUNDA ${ }^{1}$, JOG INDER SING ${ }^{1}{ }^{1}$ and DEEPAK VYAS ${ }^{2}$ \\ ${ }^{1}$ Department of Micrdaidogy, Sdhod of Biosieneesand Bictechndogy, \\ Lody Professional Univerity, Phagnara, Punjab India \\ ${ }^{2}$ Laboratory of Miơdial Teehndogy andPlant Pathology, Departmett of Botany, \\ DrHS Garr Univesity (A Central Univesity), Sagar, Madhya Pradesh470003, Inda
}

Received 22 January 2014/ Accepted 21 June 2016

\begin{abstract}
ABST RACT
Groundnut shell which is rich in natural cellulose was assessed as a substrate for production of cellulase enzyme by cellulolytic bacteria. In the present investigation the bacterial isolate Baillus subtilis M1 was found to be capable of producing high amount of endoglucanase and exoglucanase on alkali treated groundnut shell. The effect of some nitrogen sources, amino acids and $\mathrm{Ca}^{++}$ions in the medium containing pretreated groundnut shell were also evaluated. It was observed that $2 \%$ substrate concentration, $1 \mathrm{mM}$ calcium concentration were optimum for cellulase production. Ammonium nitrate was found to be the best among nitrogen sources tested. Asparagine, tryptophan and methionine werefound to bestimulatory for cellulase activity.
\end{abstract}

Keywords: Baallussubtilis cellulase, endoglucanase, exoglucanase, groundnut shell

\section{INTRODUCTION}

Microbial cellulases consist of three types of hydrolytic enzymes: 1 . endo- $(1,4)-\beta$-D-glucanase (also known as endocellulase, carboxymethyl cellulose and endoglucanase) which makes random cleavages at the b-glycosidic linkages of cellulose; 2. exo-(1, 4)- $\beta$-D glucanase (also called cellobiohydrolases and exocellulase) which hydrolyses cellobiose units from the termini of cellulose chain; and 3. $\beta$-glucosidase (synonym cellobiase) which releases glucose from cellobiose and short chain oligosaccharides (Kim \&al. 2008). The cellulases form of a very important group of enzymes that find applications in a variety of industries including textile industries, paper and pulp industries, food processing industries, wine and brewery industry etc. (Kuhad \& al. 2011). However, the cost of enzymes poses a problem to their large scale utilization, especially for the environmentally crucial processes like production of biofuels (Brijwani \& al. 2010). So, there is a need to search cheaper methods for producing

\footnotetext{
* Corresponding author: ashish.vyas@lpu.co.in
}

these enzymes. One of the possible methods for achieving this, is by using lignocellulosic wastes for the production of cellulases. Lignocellulosics offer a promising solution, since they are abundantly available and are produced in large amount as agricultural by-products.

Organic waste from renewable forest and agricultural residues are rich source of cellulose, hemicellulose and lignin (Brauns \& Brauns 1960) and therefore, can be possibly used in fermentation process for the production of cellulases. Groundnut (Aradis hypoget $\mathrm{L}$ ) is an important oil seed crop of India. The pod or dry pericarp contains about 25-40\% shell (D ey \&al. 2002). The compositional analysis of groundnut shell indicates that the shell contains cellulose $(65.7 \%)$, carbohydrates $(21.2 \%)$, protein $(7.3 \%)$, minerals (4.5\%) and lipids (1.2\%) (Masenda 2004). G roundnut shell is used as manure (Rao $\&$ al. 2009), used in mushroom cultivation (Jain \& Vyas 2002), and in production of extracellular enzymes (Vyas \&al. 2005).

The capacity of selected Baallus subtilis to produce and secrete large quantities of 
extracellular enzymes has placed them among the most important industrial enzymes producers (Schallmey \&al. 2004). This study reports Badllus subtilis M1 as potent producer of cellulase enzymes on pretreated groundnut shell.

\section{MATERIALS AN D METHODS}

\section{O rganism}

Baillus subtilis M1 was isolated from decomposing organic waste containing cellulose. Bacteria was isolated by enrichment method (Hans \& Srinivasan 1968) for which $1 \mathrm{~g}$ mixture of rotting cellulosic substrates was inoculated into the isolation medium consisting of mineral salts solution supplemented with $0.1 \%$ yeast extract and strip of filter paper. After 3 to 7 days of incubation at $30^{\circ} \mathrm{C}$ on reciprocal shaker, a patch of a yellow pigmented material appeared at the liquid air interface on the filter paper. As soon as the pigmented material appeared, a portion of filter paper was transferred with sterile wire and inoculated into fresh medium. The process was repeated several times to enrich aerobic and mesophilic cellulose utilizing organisms. The filter paper from the enriched culture was removed, macerated in a small amount of sterile water and streaked on the plates containing carboxy methyl cellulose agar. The bacterial colony was purified and maintained on Nutrient A gar Medium slants at $4^{\circ} \mathrm{C}$.

\section{Substrate}

GS (groundnut shell) was collected from local suppliers in and around Sagar District, Madhya Pradesh, India. Shell $(1 \mathrm{~kg})$ was dipped in water (5 L) to remove any amount of soluble sugar present in the substrate and then dried at $80^{\circ} \mathrm{C}$ for 36 hours in electric oven and then chopped into small pieces (Krishna 1999), which were then ground in an electric grinder and sieved through $100 \mu \mathrm{m}$ mesh sieve and kept at ro om temperature.

\section{Pretreatment of GS}

Powdered groundnut shell was treated separately with alkali $(\mathrm{NaOH})$ and designated as sample ATRT (alkali treated), while acid ( $\mathrm{HCl})$ treated shells were labeled as sample AcTRT (acid treated). D ried and powdered shell (100 g) was treated for 24 hours with $0.25 \mathrm{~N} \mathrm{NaOH}(500 \mathrm{~mL})$ (Koijam \&al. 2000) and with $0.25 \mathrm{~N} \mathrm{HCl}(500 \mathrm{~mL}$ ). After treatment the powdered shell was repeatedly washed with distilled water until it reached neutral $\mathrm{pH} 7$ and then dried over night at $60^{\circ} \mathrm{C}$.

\section{Inoculum Preparation}

Bacterial inoculum consisted of $2 \mathrm{~mL}$ of 24 hours old culture grown on nutrient broth giving absorbance of 1.2 at $660 \mathrm{~nm}$.

\section{Fermentation Medium (Submenged)}

Mandels and Reese medium (Mandels \& Reese 1957)was used for cellulase production. Chemical composition of medium was Proteose peptone, 1.0; $\left(\mathrm{NH}_{4}\right)_{2} \mathrm{SO}_{4}, 1.4 ; \mathrm{KH}_{2} \mathrm{PO}_{4}, 2.0 ; \mathrm{NH}_{2}-\mathrm{CO}-\mathrm{NH}_{2}$, $0.3 ; \mathrm{MgSO}_{4} .7 \mathrm{H}_{2} \mathrm{O}, 0.3 ; \mathrm{CaCl}_{2}, 0.3 ; \mathrm{FeSO}_{4} .7 \mathrm{H}_{2} \mathrm{O}$, 0.005; $\mathrm{MnSO}_{4} \cdot \mathrm{H}_{2} \mathrm{O}, 0.0016 ; \mathrm{ZnCl}_{2}, 0.0017$; and pretreated lignocellulosic substrate $(\mathrm{GS}), 10 \mathrm{~g} / \mathrm{L}$; 1,000 mL distilled water; $\mathrm{pH} 5.3$.

\section{Cellulase Production}

The medium $(25 \mathrm{~mL}$ ) was dispensed in $150 \mathrm{~mL}$ conical flask and autoclaved at 15 psi for 15 minutes. The flasks were inoculated with bacterial culture and incubated at $37 \pm 1^{\circ} \mathrm{C}$ under stationary conditions. The samples $(10 \mathrm{~mL})$ were withdrawn aseptically after the $6^{\text {th }}$ day of incubation and supernatant was obtained after centrifugation at 9,500 rpm for 20 minutes. The supernatant obtained was used for enzymatic activity. The control consisting of untreated GS was also run simultaneously. All tests were performed in duplicate.

\section{Enzyme Assay}

Endoglucanase and exoglucanase activities were measured (Mandels 1974) in terms of International Unit (IU), which is micromoles $(\mu \mathrm{m})$ of glucosereleased/ minute/ $\mathrm{mL}$.

\section{RESULTS AND DISCUSSION}

Cellulases are a group of industrially important enzymes and their demand is increasing day by day with the growth of enzyme industry. G roundnut shell was assessed as cheap alternative lignocellulosic substrate for producing 
cellulase enzymes sinceit is known to possess high percentage of cellulose (Masenda 2004). However, the lignin present in the groundnut shell can impede the cellulase enzymes. So, delignification was performed through alkali $(\mathrm{NaOH})$ and acid $(\mathrm{HCl})$ pretreatment. In the present investigation, the isolate M1 was found to be potent producer of cellulase enzymes on pretreated groundnut shell. It was isolated from decomposing organic waste containing cellulose as per the enrichment method described by Hans and Srinivasan (1968). Microorganism found was gram positive, spore producing, catalase positive rod shaped bacterium. It was identified as Baillus subtilis by IMTECH (Institute of Microbial Technology), Chandigarh, India.

Under the conditions of $\mathrm{pH} \mathrm{5}$, temperature $50{ }^{\circ} \mathrm{C}$ and an incubation period of 6 days, the bacterial isolate B. subtilis M1's endoglucanase activity was found to be 2 fold $(0.314 \mathrm{IU} / \mathrm{mL})$ and exoglucanase activity was found to be 3.3 fold (0.043 FPU/ mL) in ATRT GS as compared to untreated GS. In AcTRT GS, 1.5 fold $(0.219 \mathrm{IU} / \mathrm{mL})$ increased endoglucanase and 1.5 fold $(0.020 \mathrm{FPU} / \mathrm{mL})$ exoglucanase activity was obtained as compared with the untreated. So, the pretreatment resulted in higher enzyme production and the alkali treatment was found to be more efficient than the acid treatment (Fig. 1). Alkali $(\mathrm{NaOH})$ treatment of $\mathrm{GS}$ was found to be more superior to acid $(\mathrm{HCl})$ treatment as it modifies lignocellulosic substrate by increasing the pore size and solubilizing lignin and hemicellulose. It increases the surface area of cellulose, reducing its crystallinity (Ming \& al. 2008).

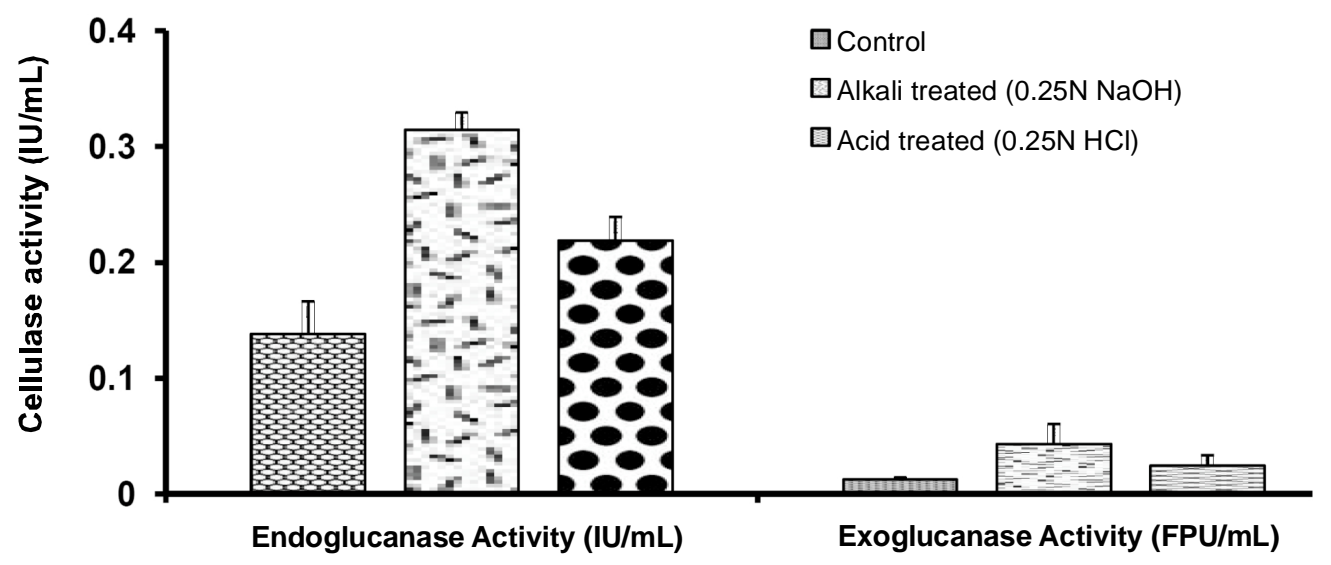

Figure 1 Effect of alkali and acid treatments of groundnut shell on production of cellulase by BaillussubilisM1

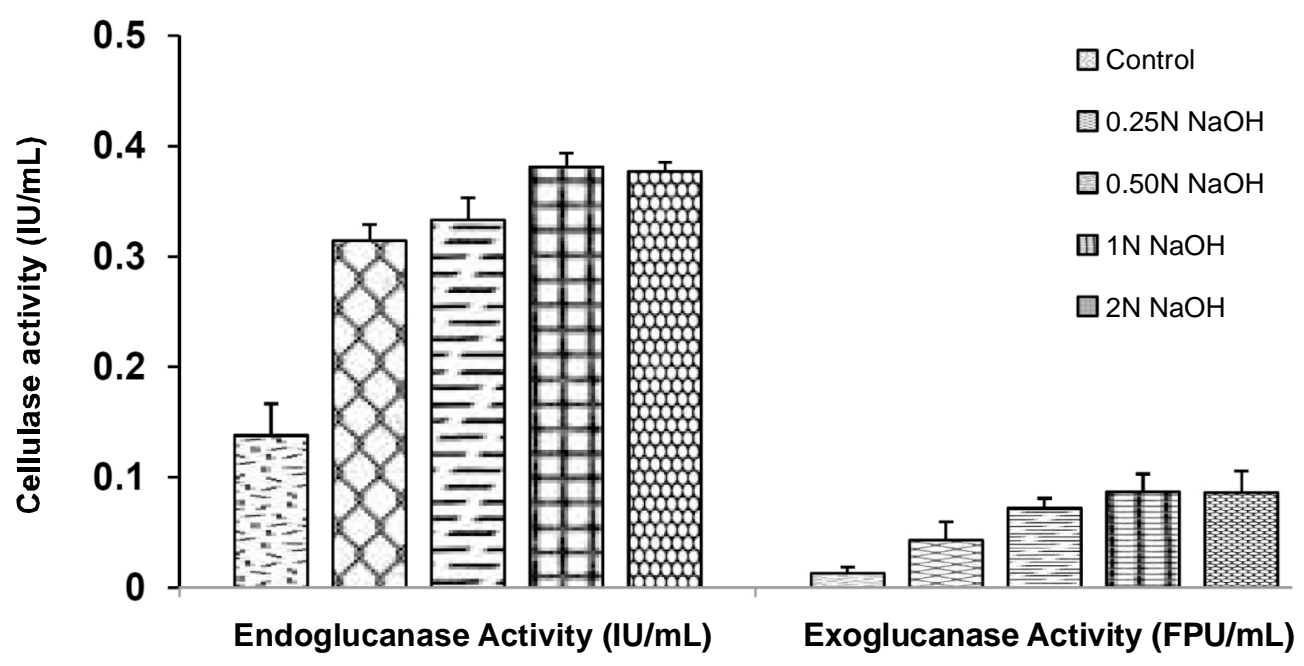

Figure 2 Effect of alkali pretreatment of different concentrations on groundnut shell on cellulase production by Baallus subtilisM1 


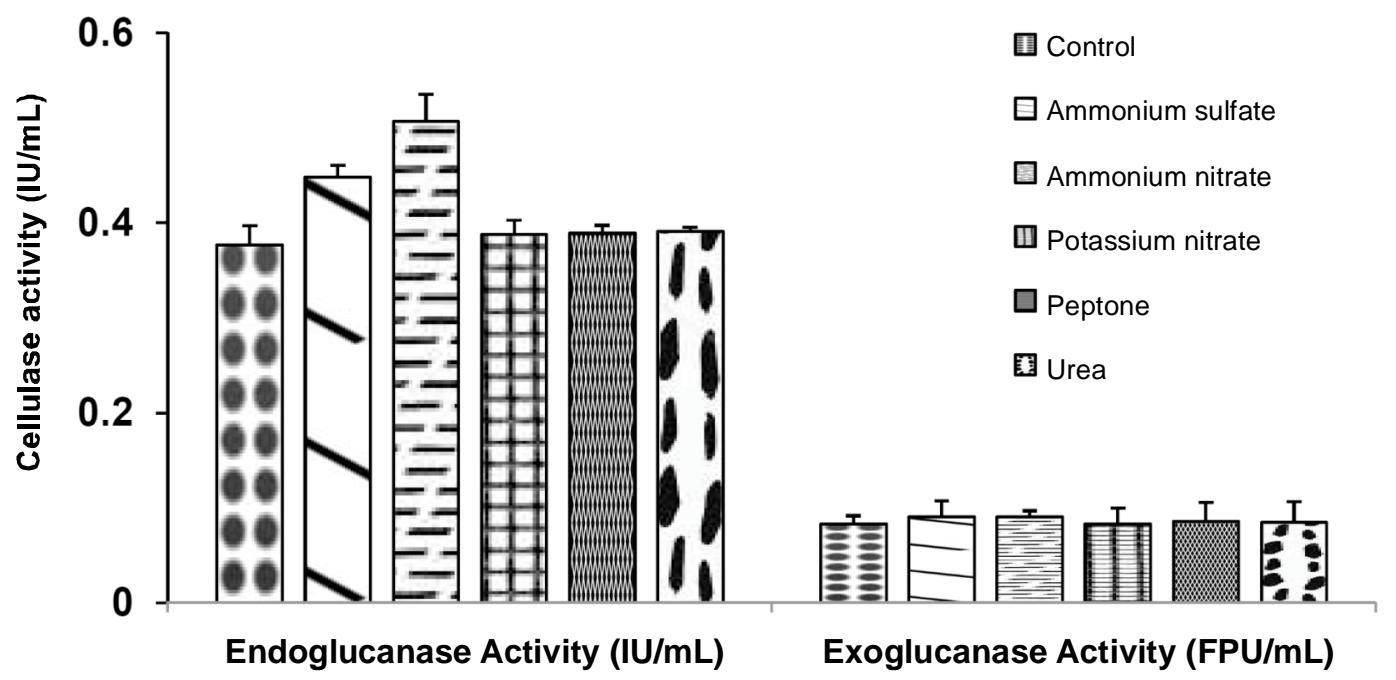

Figure 3 Effect of nitrogen sources on cellulase production on alkali treated groundnut shell by BaillussubtilisM1

Pretreatment of powdered GS at different alkali concentrations $(0.25 \mathrm{~N}, 0.5 \mathrm{~N}, 1 \mathrm{~N}, 2 \mathrm{~N}$ $\mathrm{NaOH}$ ) showed that $\mathrm{B}$. subtilis $\mathrm{M} 1$ produced the highest endoglucanase $(0.381 \mathrm{IU} / \mathrm{mL})$ and exoglucanase (0.087 FPU/ $\mathrm{mL}$ ) activities in case of $1 \mathrm{~N} \mathrm{NaOH}$ treated GS. Endoglucanase activity was increased by 2.7 fold and exoglucanase activity by 6.9 fold higher compared to untreated G S (Fig. 2). The increased cellulase activity at $1 \mathrm{~N}$ $\mathrm{NaOH}$ concentration might be due to increased solubilization of lignin and increase in swelling of cellulose I to cellulose II. Aguiar (2001) also reported $1 \mathrm{~N} \mathrm{NaOH}$ pretreatment of lignocellulosic substrates as best source for cellulase production. Chemical pretreatment of lignocellulosic material followed by its hydrolysis suggested that accessible surface area is a key determinant for enhancing cellulase yield. However, Sarkar and Aikat (2012) reported the highest activity of cellulases by Aspergllusfumigatus NITDGPKA3 on rice straw pretreated with $0.5 \mathrm{MNaOH}$.

The amount of nutrients present in the production medium is one of the major factors impacting the microbial enzyme production. The effect of five nitrogen sources (ammonium sulfate, ammonium nitrate, potassium nitrate, peptone, urea) were tested separately (Fig. 3).

Each nitrogen source was added in equivalent amount to the total nitrogen present in the medium (587 mg nitrogen/ L medium) keeping the available nitrogen constant. Ammonium nitrate was found to be the best for endoglucanase activity (0.507 IU/ mL) and exoglucanase activity (0.091 FPU/ mL) followed by ammonium sulfate, potassium nitrate, peptone and urea. Nitrogen is the major constituent of protoplasm and building block of enzymes (proteins). Sethi $\notin$ al. (2013) also reported ammonium salt to be excellent source of nitrogen for cellulase production and concluded that this may be due to their direct entry of ammonium ion in protein synthesis.

Similarly, amino acids are nitrogen containing organic compound and therefore, have influence on cellulase synthesis, but the specific side groups present on the amino acids can also play somerole in cellulase synthesis. Among various amino acids added to the medium $(0.2 \mathrm{w} / \mathrm{v})$, Tryphtophan $(0.675 \mathrm{IU} / \mathrm{mL})$, asparagine $(0.629 \mathrm{IU} / \mathrm{mL})$ and methionine ( $0.564 \mathrm{IU} / \mathrm{mL}$ ) were found to be the better suited for endoglucanase activity (Fig. 4). On the other hand, alanine, arginine and threonine were found to be suppressive in action. B. subtilis M1 showed maximum exoglucanase activity in the presence of asparagine $(0.126$ FPU/mL) followed by metheonine $(0.108$ FPU/mL) and tryptophan (0.095 FPU/ mL). Amino acids, being the building blocks of protein, have a profound influence in the cellulase synthesis of bacteria. The increased production might be due to the enhanced synthesis of cellulolytic enzymes in the presence of amino acids. Asparagine and metheonine were found to be stimulatory for cellulase activity in Aspergillus terras AV49 by Vyas \& al. (2005). 


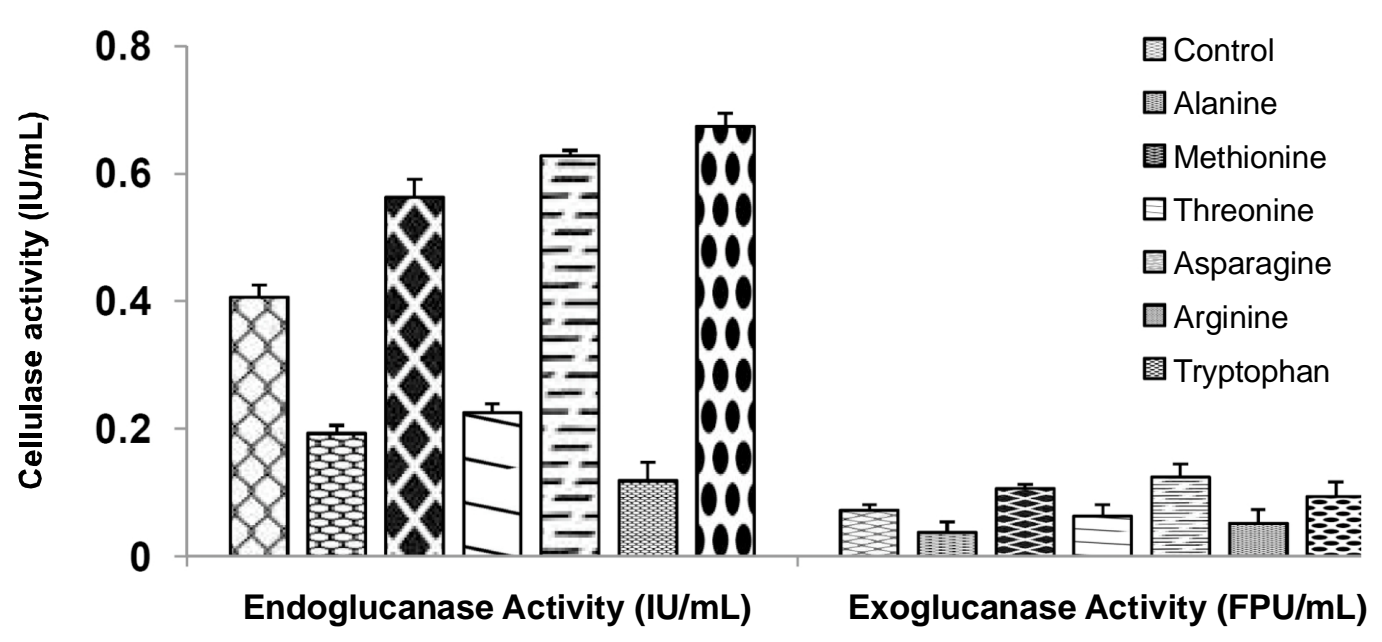

Figure 4 Effect of different amino acids on cellulase production on alkali treated groundnut shell by BaillussubilisM1

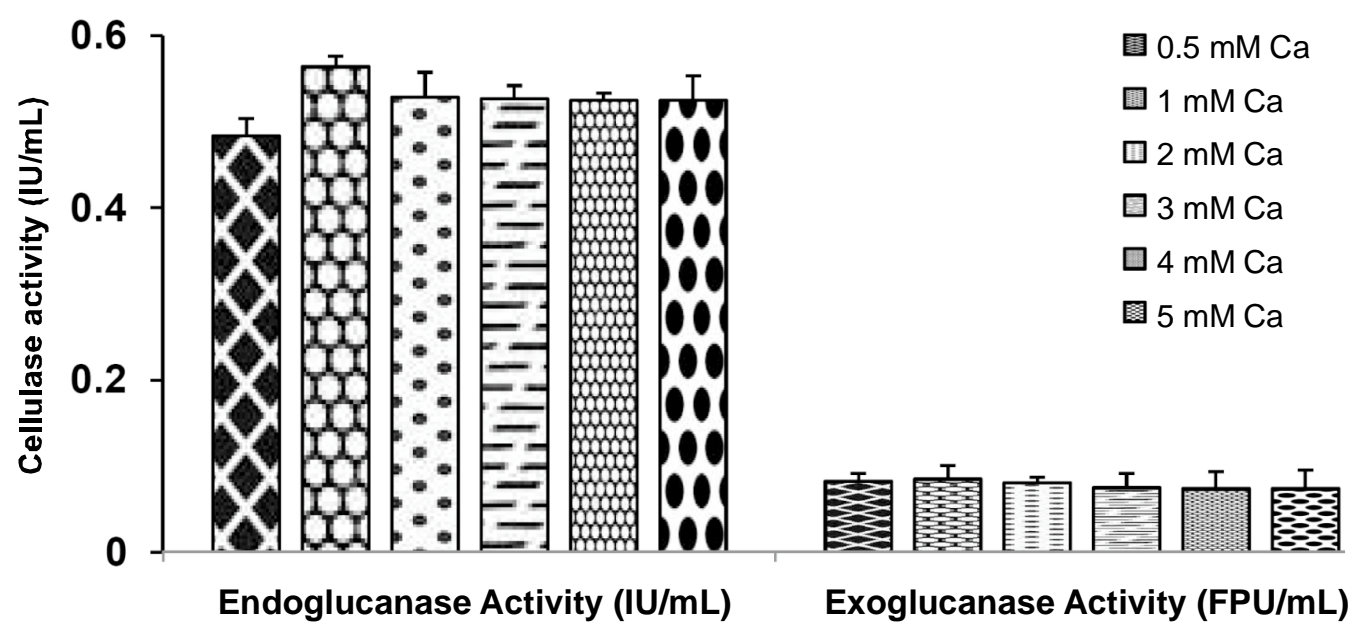

Figure 5 Effect of calcium concentration on cellulase production on alkali treated groundnut shell by BaallussubtilisM1

The activity and stability of various enzymes are known to be impacted by various ions. Different concentrations of calcium $(0.5-5 \mathrm{mM})$ had differential impact on the enzymatic activity (Fig. 5). Low (1 mM) concentration produced maximum endoglucanase activity $(0.564 \mathrm{IU} / \mathrm{mL})$. However, at higher concentration $(2-5 \mathrm{mM})$ endoglucanase activity was almost static, yet remained higher than control. Exoglucanase activity was maximum $(0.085 \mathrm{FPU} / \mathrm{mL})$ at $1 \mathrm{mM}$ concentration and thereafter, it decreased up to $5 \mathrm{mM}$.

Metal ions are generally cellulase stimulators at low concentration, whereas inhibitory at very high concentration. $\mathrm{Ca}^{++}$was found to positively influence the activity of cellulase at concentrations less than $1 \mathrm{mmol} / \mathrm{L}$ by Wang $\notin$ al.
(2012). In the present study, $\mathrm{Ca}^{++}(1 \mathrm{mM})$ was found to be stimulatory and higher concentration showed static endo- and exoglucanase activities by B. subtilis $\mathrm{Ca}^{++}(10 \mathrm{mM})$ is reported (Kim \&al. 2001) to be stimulatory for cellulase (exoglucanase) activity in Tridhodema rese. Strong affinity and tightness of the enzymes would disrupt the hydrogen bonding network in the crystal lattice, ultimately collapsing the ordered structure of cellulose particles and preventing adhesion. Kotchoni \& al. (2003), however, reported enhanced cellulase activity at low calcium concentration (1 $\mathrm{mM})$ in Badllus pumilusBpCRI6.

The effect of substrate concentration is also known to impact the enzyme activity. In the present investigation it was observed that with 


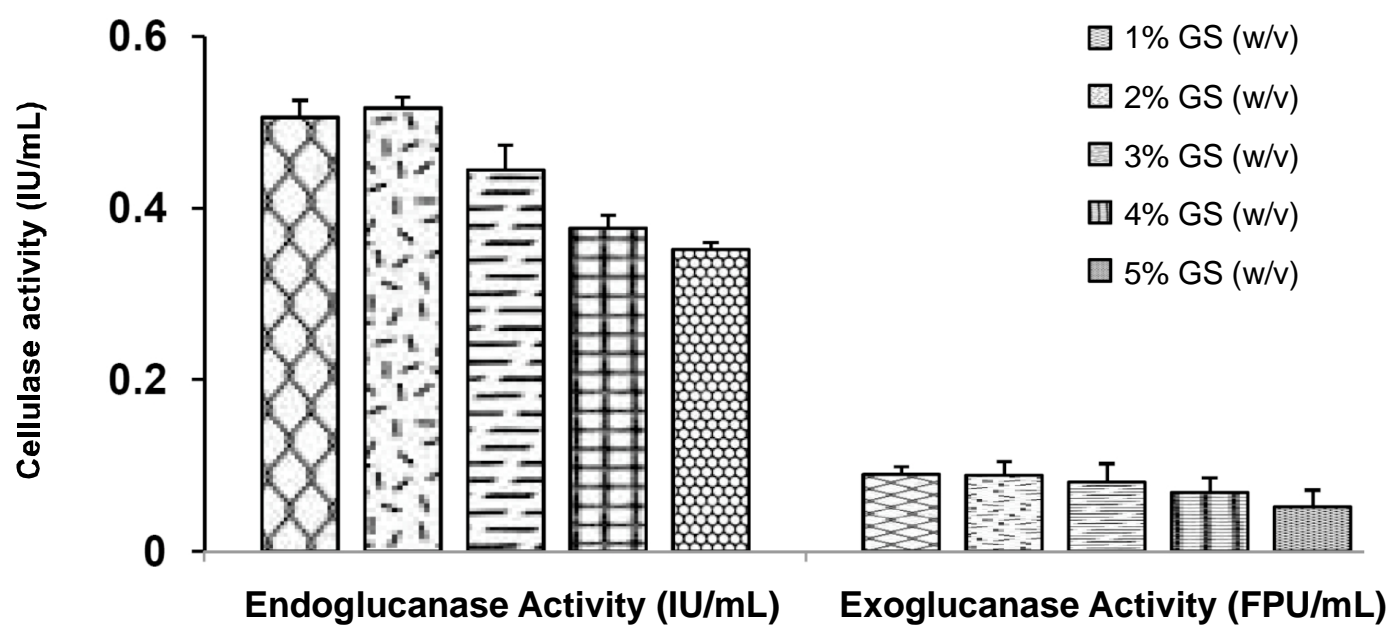

Figure 6 Effect of substrate concentration on cellulase production on alkali treated groundnut shell by BaallussubtilisM1

increased substrate concentration, the endoglucanase activity showed increasing trend up to $2 \%$ substrate concentration $(0.517 \mathrm{IU} / \mathrm{mL})$, thereafter, no further increase in activity was observed (Fig. 6). Maximum exoglucanase activity was observed at $1 \%$ substrate concentration (0.090 FPU/ mL). O konkwo (2014) also observed maximum activity at $1 \%$ substrate concentration in case of cellulase produced by Aspergillusflaws

\section{CONCLUSIONS}

The present findings raise the possibility of using groundnut shell as a substrate for production of cellulase enzymes by Badllussubtilis M1. The cultural conditions as well as the type of pretreatment also seem to have profound impact on the enzyme activity. There is a need to assess the production at pilot plant scale, so that it can be used subsequently at the commercial scale in the longrun.

\section{ACKNOWLEDGEMENTS}

The first author thanked the Head of Botany D epartment, Dr HS Gour University for providing necessary laboratory facilities during research tenure. Thanks are also due to Prof M.K. Bhat, Institute of Food Research, Colney, Norwich, England for providing relevant literature

\section{REFERENCES}

Aguiar CL. 2001. Biodegradation of the cellulose from sugarcane bagasse by fungal cellulase. Cienc Tecnol Aliment3:117-21.

Brauns FE, Brauns DA. 1960. The Cheristry of Ligin Coveing the Literature for the 1949-1958. San D iego (USA):Academic Press San D iego.

Brijwani K, O beroi HS, Vadlani PV. 2010. Production of a cellulolytic enzyme system in mixed-culture solidstate fermentation of soybean hulls supplemented with wheatbran. Process Biochem 45:120-8.

Dey R, Pal KK, Chauhan SM, Bhatt DM, Misra JB. 2002. Groundnut shell decomposition potential of some cellulolytic microorganisms. Ind J Microbiol 42: 165-7.

Hans YW, Srinivasan VR. 1968. Isolation and characterization of cellulose utilizing bacterium. App Microbiol16:1140-5.

Jain AK, Vyas D. 2002. Yield response of Plemctusflocidaon wheat straw in combination with other substrates. Mushroom Res 11:19-20.

Kim DW, Jang YH, Kim CS, Lee NS. 2001. Effect of metals ions on the degradation and adsorption of two cellobiohydrolases on microcrystalline cellulose. Bull Korean Chem Soc 22:716-20.

Kim SJ, Lee CM, Han BR, Kim MY, Yeo Y S, Yoon SH, Koo BS, Jun HK. 2008. Characterization of a gene encoding cellulase from uncultured soil bacteria. FEMSMicrobiol Lett 282:45-51.

Koijam B, Sharma NC, Gupta S. 2000. Production and characterization of fungal cellulase from cellulosic waste. Asian J Microbiol Biotechnol Environ Sci 4:113-20.

Kotchoni O S, Shonukan O O, Gachomo WE. 2003. Baillus pumilusBpCRI 6, a promising candidate for cellulase production under condition of catabolite repression. AfrJ Biotechnol 2:140-6. 
Krishna C. 1999. Production of bacterial cellulases by solid state bioprocessing of banana wastes. Biores Technol 69:231-9.

Kuhad RC, Gupta R, Singh A. 2011. Microbial cellulases and their industrial applications. Enzyme Research [Internet]. [cited 2015]; article ID 280696. Available from: http:/ / www.hindawi.com/ journals/ er/ 2011/280696/ doi:10.4061/ 2011/ 280696.

Mandels M, Reese ET. 1957. Induction of cellulases in fungi in Tridodemavindeas influenced by carbon source. J Bacteriol 37:269-78.

Mandels M. [Internet]. 1974. Laboratory procedures, hand book. USA: US Army Natick Laboratories. Available from: http:// calvin.biotech.wisc.edu/ jeffries/ cellulases/ mandels.html.

Masenda E. [Internet]. 2004. Groundnut shells, substrate. Mushroom Growers Handbodk I. South Korea: MushWorld. p 120-122. Available from: www.mushworld.com/ service/ handbook/ 2004/ ch apter-5-8.pdf.

Ming C, Jing Z, Liming X. 2008. Enzymatic hydrolysis of maize straw polysaccharides for the production of reducingsugars. Carbohydr Polym 71:411-5.

O konkwo IF. 2014. Effect of substrate concentration on the activity of cellulase produced by Aspergillus flams IndJ App Res 7: 32-4.
Rao CS, Wani SP, Sahrawat KL, Rajasekharao B. 2009. Nutrient management strategies in participatory watersheds in semi arid tropical India. Ind J Fert 5(12):113-28.

Sarkar N, Aikat K. 2012. Alkali pretreatment of rice straw and enhanced cellulase production by a locally isolated fungus Aspergillus fumigatus NITD G PKA3. J Microbiol Biotech Res 2(5):717-26.

Schallmey M, Singh A, Ward OP. 2004. Developments in the use of Baillusspecies for industrial production. Canadian J Microbio 50(1):1-17.

Sethi S, D attaA, Gupta BL, GuptaS. 2013. Optimization of cellulase production from bacteria isolated from soil. ISRN Biotechnology [Internet]. 2013:985685. Available from: http:// www.hindawi.com/ journals/ isrn/ 2013/ 985685/ doi: 10.5402/ 2013/ 985685.

Vyas A, Vyas D, Vyas KM. 2005. Production and Optimization of Cellulases on Pretreated Groundnut Shell by AspergillusterreasAV 49.J Sci Ind Res 64:281-6.

Wang G, Zhang X, Wang Li, Wang K, Peng F, Wang L. 2012. The activity and kinetic properties of cellulases in substrates containing metal ions and acid radicals. Adv Biol Chem 2:390-5. 